\title{
Evaluation of physicochemical and heavy metals characteristics in surface water under anthropogenic activities using multivariate statistical methods, Garra River, Ganges Basin, India
}

\author{
MohdYawar Ali Khan ${ }^{1,2,3^{\dagger}}$, Jie Wen $^{2,4}$ \\ ${ }^{1}$ Department of Hydrogeology, King Abdulaziz University, Jeddah 21589, Saudi Arabia \\ ${ }^{2}$ Department of Hydraulic Engineering, Tsinghua University, Beijing- 100084, China \\ ${ }^{3}$ Department of Earth Sciences, Indian Institute of Technology Roorkee, Roorkee - 247667, India \\ ${ }^{4}$ China Institute of Water Resources \& Hydropower Research (IWHR), Beijing 100044, China
}

\begin{abstract}
Water samples from twenty-six locations were collected during March 2014, to evaluate the spatial variation in the water quality of Garra River, Ganges Basin. The physicochemical and heavy metals concentration along the river water were significantly different between the natural and urbanized areas. In the case of the mainstream, the chemical oxygen demand (COD) and the biological oxygen demand (BOD 5 ), which indicate the levels of organic pollution of the river water, were in the range of $8.1-51.4 \mathrm{mg} / \mathrm{L}$ and $5.8-26.9 \mathrm{mg} / \mathrm{L}$, respectively. On the other hand, in the case of tributaries, these values were in the range of $19-36 \mathrm{mg} / \mathrm{L}$ and $11.2-20 \mathrm{mg} / \mathrm{L}$, respectively. Multivariate statistical analysis was also carried out to discriminate sources of spatial variation of water quality. The results of principal component analysis (PCA) show the relationship between physicochemical parameters suggesting that the quality of water is mostly controlled by carbonate weathering. Dolomite is most likely to be present, which is a common source of $\mathrm{Ca}^{+}$and $\mathrm{Mg}^{+}$. Spatial distribution of $\mathrm{PO}_{4}^{3-}$ with a high concentration in the downstream area of river (average $0.35 \mathrm{mg} / \mathrm{L}$ ) suggests runoff from agricultural fields in this region as the main source.
\end{abstract}

Keywords: Garra River, Ganges Basin, Heavy metals, Multivariate statistical analysis, Water quality

\section{Introduction}

Surface water quality is one of the most critical environmental concerns in many parts of the world. Manahan [1] stated that surface water consists of all the water that flows through landmasses like creeks, springs, lakes, rivers and oceans. A stream is a system involving mainstream rivers and tributaries that transports a one-way flow of large amounts of particulate and dissolved load from both anthropogenic and natural sources. At any point, the chemistry of surface water of a river reflects several noteworthy influences, including atmospheric inputs, the lithology of the basin, anthropogenic inputs and climatic conditions [2]. Natural (erosion) and anthropogenic (agricultural discharge) activities affect the quality of regional surface water [3-10]. According to Finnveden et al. [11], crop waste, degradable solid waste and food waste contribute to the organic content of surface water. Nutrients such

This is an Open Access article distributed under the terms of the Creative Commons Attribution Non-Commercial License (http://creativecommons.org/licenses/by-nc/3.0/) which permits unrestricted non-commercial use, distribution, and reproduction in any medium, provided the original work is properly cited.

Copyright (C) 2021 Korean Society of Environmental Engineers as nitrogen $(\mathrm{N})$ and phosphorus $(\mathrm{P})$ cause the growth of algae and phytoplankton, leading to eutrophication. River water quality research helps to develop water management and pollution prevention strategies. Examining the water quality of the river by considering its organic and physicochemical properties helps to reduce the implication in the clarification of water quality due to spatial variations [12].

Recent research has increasingly focused on planning new monitoring strategies [13, 14], in which multivariate statistical techniques such as PCA and hierarchical cluster analysis (HCA) have emerged. These methods have been used to assess the effectiveness of surface water quality monitoring networks, plans to increase the number of examining stations and select the basic parameters of water quality. Along these lines, it is conceivable to identify and evacuate stations as well as repetitive parameters to reduce the economic cost of monitoring plan without sacrific-

Received May 27, 2020 Accepted November 18, 2020

${ }^{\dagger}$ Corresponding author

Email: makhan7@kau.edu.sa

Tel: +966-545274691

ORCID: 0000-0001-6524-4733 
ing fluctuation in water quality data. A typical drawback of such techniques is that they can only focus on identifying monitoring locations to be discontinued. This is a consequence of the evaluation being centered on the data of water quality already acquired, ignoring the attributes of the river basin under investigation [13]. Despite this, PCA and HCA have been greatly recognized and widely used in monitoring plans, optimizing spatial sampling points and determining the most appropriate water quality factors [15-24].

The Ganges is an indispensable sacred river in India, especially for the widely practised Hindu religion in the country. In the past few decades, the water quality of the river has deteriorated due to anthropogenic factors, which has led to many national and international organizations to analyze and develop plans to clean the river. In 2009, the National Ganga River Basin Authority (NGRBA) was established under the Environment (Protection) Act of 1986 to clean up the Ganges [25]. The main tributaries are also important contributors to pollution; therefore, conversation strategies should also apply to tributaries.

The tributaries of the Ganges that have been well studied are Gomti, Hindon, Yamuna and Ramganga [26-35]. However, the important tributary in terms of pollution, the Garra River, lacks such an assessment. This river acts as a discharge point for the treated wastewater effluents in adjacent cities. Due to the diversity of the catchment area, anthropogenic and non-anthropogenic pollution sources were discovered along the river.

Therefore, this study investigated the assessment of physicochemical parameters and heavy metals in the water quality of the Garra River and its tributaries and identified the contaminated stretches of the river. This survey was designed to assess the productivity of the Garra River water quality monitoring network using PCA, HCA, Pair sample $t$ - test, and one way ANOVA. Subsequently, it is recommended to identify sampling locations that are critical to the monitoring plan; select the most detailed water quality parameters and assess potential sources, either anthropogenic or natural-based, which will affect the water quality of each sampling location. Therefore, there is a need to contribute to changes in the monitoring plan and to guide executives in decision-making and priorities.

\section{Study Area}

The Garra River originates from the eastern part of the Nainital district of the Kumaon Himalayas, Uttarakhand state (Fig. 1). The total length of the river is $382 \mathrm{~km}$ of which the initial $41 \mathrm{~km}$ flowing in the Kumaon Himalayas. The river enters in the Ganga Flood Plains (GFP) at Nanakmatta town, where the famous Nanaksagar dam has been built. After the confluence of the Ramganga, another major tributary of the Ganges, the river is connected to the Ganges River in the Kannauj area of Uttar Pradesh [36-39]. The average elevation of the Garra river is $530 \mathrm{~m}$ above sea level (a.s.l) with a total catchment area of $6,832 \mathrm{~km}^{2}$.

In GFP, river flow through densely populated districts and highly industrial and agricultural areas of Uttar Pradesh state, such as Pilibhit, Shahjahanpur, Hardoi and Kannauj. The river serves as

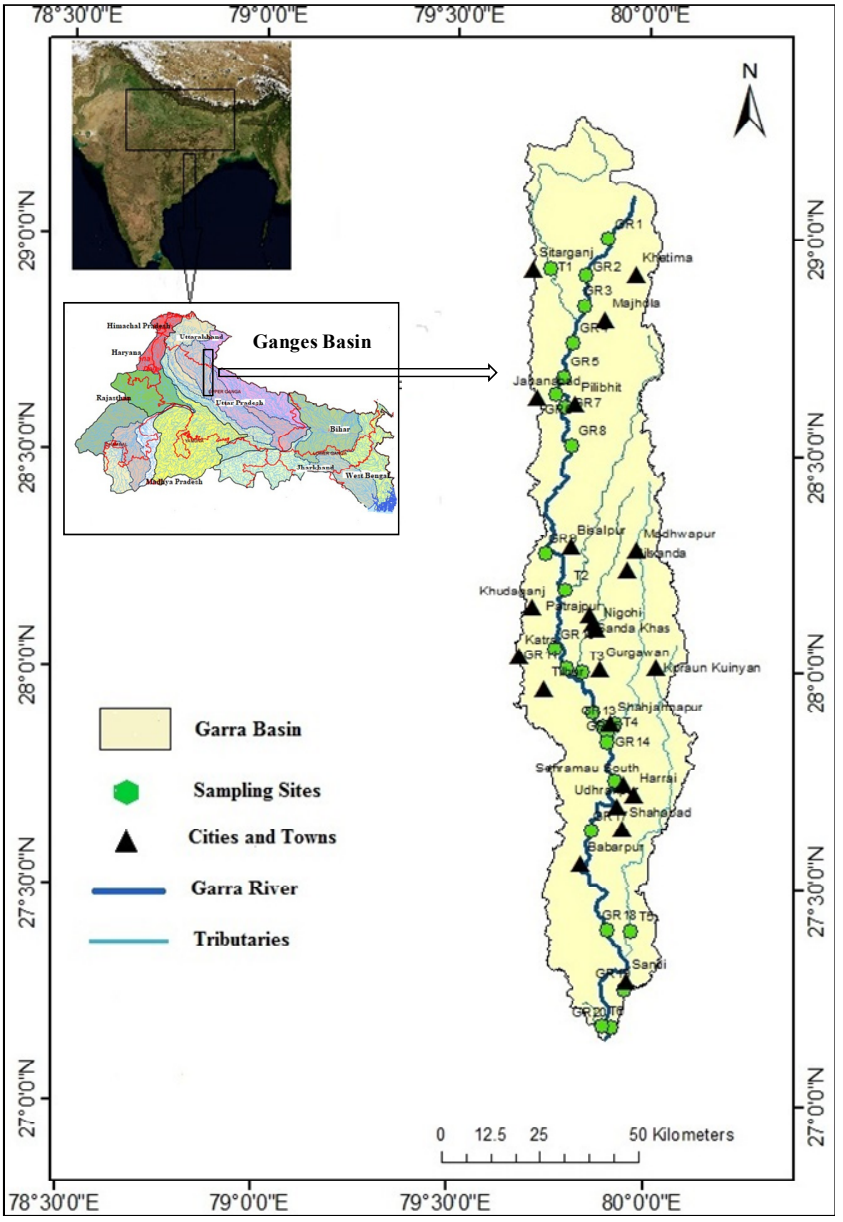

Fig. 1. Map showing the area of study and sampling locations.

a source of water for domestic and agricultural purpose. The diversity of the river has implications on the pollution sources as both natural and anthropogenic pollution sources are being present. This makes its study interesting and challenging in identifying various sources of pollution.

\subsection{Physiography and Relief}

Due to The contrast between the landform, slope and elevation, the entire catchment area shows a large variation in weather and climate (Fig. S1). The annual average precipitation in the catchment area is about $1,000 \mathrm{~mm}$, controlled by Indian monsoon (http://www.indiawaterportal.org/met_data/). The altitude of the river ranges from less than $150 \mathrm{~m}$ a.s.l for GFP to more than $2,000 \mathrm{~m}$ a.s.l for the Himalayas (Fig. S1(a) and S1(b)). The minimum slope of the river is shown in GFP, which is about $0-1 \%$, and in the Himalayas, it is greater than 15\% (Fig. S1(b)). From Fig. S1(d), it is evident that the population density of the catchment area ranges from below 1,000,000 in the Himalayas to more than $3,000,000$ in GFP.

\subsection{Geology}

In the mountain, the catchment constitutes the major lithotectonic 
zones, namely Sub-Himalayas consisting of siltstone, clays, sandstones and boulders. It shows the characteristics of the molasse sediments of Mid-Miocene to Pleistocene [40]. In GFP, which is closely linked with the extension of the Himalayan orogenic belt, the basin area represents the quaternary lithostratigraphic sequence, including (1) Varanasi Older Alluvium with two facies i.e. sandy facies and silt clay facies, (2) Ganga/Ramganga Terrace Alluvium and (3) Ganga/Ramganga Recent Alluvium. The latter two constitute the Newer Alluvium [41].

\section{Materials and Methods}

\subsection{Description of the Sampling Sites and Analysis}

Fig. 1 shows 26 sampling sites that were consciously identified and observed along the $382 \mathrm{~km}$ stretch of the Garra River. Five liters of the river water were collected in the month of March, 2014 from each sampling location. According to the standard protocols [42], all samples have been preserved and transferred to the laboratory. Digital meters (HACH Instruments) were used to measure the $\mathrm{pH}$ and electrical conductivity (EC) of each water sample. Total dissolved solids (TDS) and temperature were measured by using an automatic TDS meter (HACH Instruments) and a mercury thermometer (HACH Instruments), respectively. The Winkler Azide method and the molybdate ascorbic acid method were used to determine chemical oxygen demand (COD) and phosphate $\left(\mathrm{PO}_{4}{ }^{3-}\right)$, respectively (Spectrophotometer, HACH). On the other hand, the dichromate reflux method was used to determine the biological oxygen demand $\left(\mathrm{BOD}_{5}\right)$. Ion chromatographer (IC) (Metrohm 782 Basic IC) was used to determine the concentration of potassium $\left(\mathrm{K}^{+}\right)$, magnesium $\left(\mathrm{Mg}^{2+}\right)$, sodium $\left(\mathrm{Na}^{+}\right)$, calcium $\left(\mathrm{Ca}^{2+}\right)$, lithium $\left(\mathrm{Li}^{+}\right)$, chloride $\left(\mathrm{Cl}^{-}\right)$, fluoride $\left(\mathrm{F}^{-}\right)$, sulfate $\left(\mathrm{SO}_{4}{ }^{2-}\right)$, nitrate $\left(\mathrm{NO}_{3}{ }^{-}\right)$and bicarbonate $\left(\mathrm{HCO}_{3}{ }^{-}\right)$. The ion instrument was calibrated by using a standard solution of cations and anion eluents. The IC detection limit of various cations and anions was $0.1 \mathrm{mg} / \mathrm{L}$.

The concentrations of heavy metals such as iron (Fe), zinc $(\mathrm{Zn})$, and manganese $(\mathrm{Mn})$ were measured by an atomic absorption spectrometer (AAS) (THERMO FISHER. MODEL iCE3000) according to the procedure recommended by Environmental Protection Agency (EPA, Method 3005A). All samples were filtered using a $0.45 \mu \mathrm{m}$ cellulose nitrate membrane and digested with aquaregia $\left(\mathrm{HNO}_{3} 67 \%\right.$ : $\mathrm{HCl} 37 \%=3: 1$ ). The samples were covered with ribbed watch glass and heated on a hot plate at 90 to $95^{\circ} \mathrm{C}$ until the volume was reduced to $15-20 \mathrm{~mL}$. All lamps used in AAS for heavy metal analysis were a hollow cathode. The detection limit were $0.05 \mathrm{mg} / \mathrm{L}$, $0.001 \mathrm{mg} / \mathrm{L}, 0.01 \mathrm{mg} / \mathrm{L}$ for Fe, Zn, and Mn, respectively. To maintain the quality of the data of each processed sample, a blank was carried throught the analysis and sample preparation. These blanks may help determine if the sample is contaminated.

\subsection{Software Used for Statistical Analysis}

Excel 2003, a part of the Microsoft Office Suite, SPSS 10 (IBM Corporation, Windows version) and STATISTICA 6 (StatSoft, Inc.) were used. Statistical analysis such as HCA, paired sample t-test, PCA, and analysis of variance (ANOVA) with a confidence level of $\mathrm{p}<0.05$ were used.

\section{Results and Discussion}

The examination of the physicochemical and heavy metals characteristics in this study was subjected to statistical analysis and evaluated to their recommended values prescribed in the Bureau of Indian Standard [43] and the World Health Organization [44] (as shown in Table S1).

\subsection{Physicochemical Characteristics}

Salt solubility, biodegradation, physicochemical parameters and dissolved oxygen rate are exaggerated by temperature [45]; therefore it plays an important role in a riverine system. The temperature of the Garra River and its tributaries range between $24.9^{\circ} \mathrm{C}$ to $31.8^{\circ} \mathrm{C}$ with an average of $28.9^{\circ} \mathrm{C}$, which is higher than the recommended values by the BIS [43] and WHO [44] (Fig. S2(a)). Generally, the upstream temperature values are lower compared to the middle and downstream. The increase in solar radiation from the morning to noon may be the reason for variation in temperature values (Fig. S2(a)) because the samples were collected at different times between morning and noon.

The $\mathrm{pH}$ variation in mainstream water and its tributaries were 6.6 to 8.7 and 7.4 to 8.0 respectively. This confirms that it is slightly alkaline in nature. This is attributable to the $\mathrm{HCO}_{3}{ }^{-}$ion concentration, which is relatively high in the tributaries $(148.9 \mathrm{mg} / \mathrm{L}$ ) and the mainstream (151.1 mg/L) (Table S1). Higher $\mathrm{pH}$ values of 7.8 (GR2) and 7.6 to 8.7 (GR9-GR20) were recorded in the main river stream, while $\mathrm{pH}$ values of 8.1 (T3) and 8.0 (T5) were observed in the tributaries (Fig. S2(b)). Most samples of the Garra River and its tributaries have lower $\mathrm{pH}$ values than those set by BIS [43] and WHO [44]).

The turbidity in the stream implies the ambiguity of the water due to the presence of suspended matter of clay, silt, waste and other particulate materials. Along the Garra River, the water at the sampling stations GR9 - GR20 was found to be the most turbid, between 178 NTU - 1,355 NTU. GR10 and GR14 exhibited the lowest and highest turbidity values, respectively. In the case of tributaries, the turbidity range is between 111 NTU - 336 NTU, with $\mathrm{T} 1$ being the lowest and T6 has the highest turbidity value. Peat water from highlands due to weathering and erosion may be the cause of upstream turbidity. In the middle and downstream of the river, the contribution to turbidity is mainly due to the disturbance of the topsoil by agriculture and other processes such as sand mining, as rivers usually move downwards from hilly areas [46]. Contaminated runoff from industry, agriculture, markets and roads is the main reason for the high turbidity values of these stations (Fig. S2(b)), which are located around urbanized cities such as Pilibhit, Shahjahanpur and Hardoi.

The temperature influences the electrical conductivity (EC) of water, which is an assessment of dissolved solids in water. The average EC values in the water samples from the Garra River and its tributaries (Fig. S2(c)) were $242.6 \mu \mathrm{S} / \mathrm{cm}$ and $222.5 \mu \mathrm{S} / \mathrm{cm}$, respectively. As can be seen from Fig. S2(c), in the case of River Garra, the highest EC values are $498 \mu \mathrm{S} / \mathrm{cm}$ and $421 \mu \mathrm{S} / \mathrm{cm}$ at GR12 and GR20, respectively, while in the tributaries, the highest values is $340 \mu \mathrm{S} / \mathrm{cm}$ at T4. Fig. S2(c) shows that the change in EC is almost the same as TDS. In the case of the Garra River 

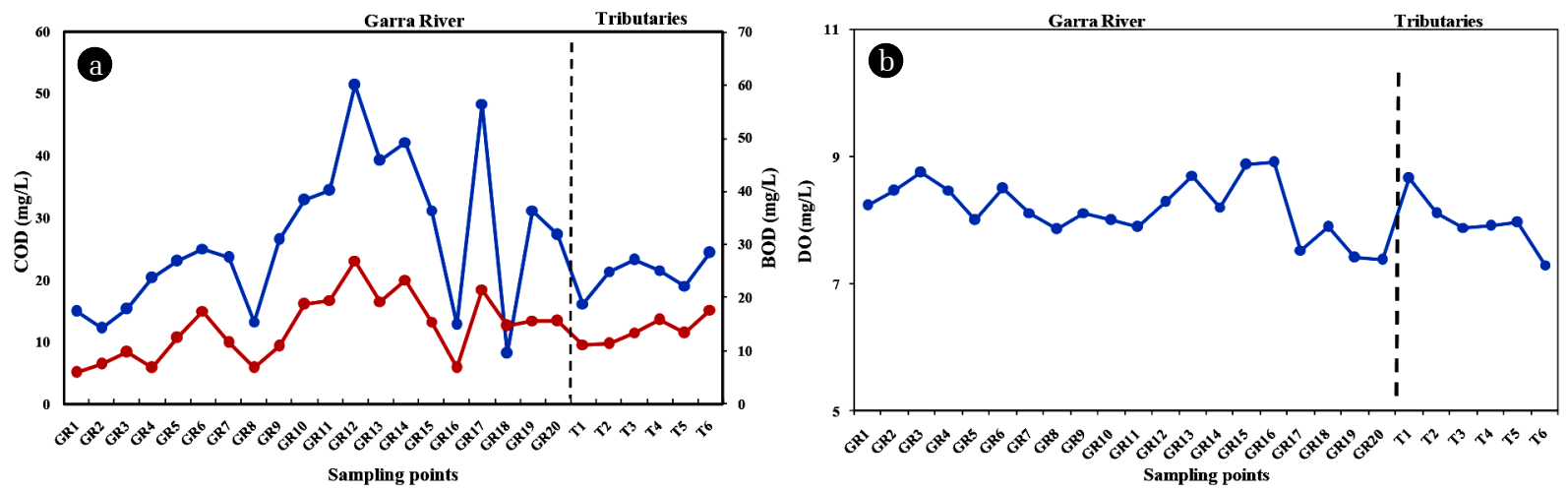

Fig. 2. Spatial variations in $\mathrm{COD}, \mathrm{BOD}_{5}$, and $\mathrm{DO}$ in water of Garra River and its tributaries.

and its tributaries, the values of EC shows an increasing pattern from upstream to downstream (Fig. S2(c)). This which may be due to the presence of inorganic dissolved solids such as $\mathrm{Cl}^{-}, \mathrm{NO}_{3}$, $\mathrm{SO}^{2-}$, and $\mathrm{PO}_{4}{ }^{3-}$ (Fig. 3(d) and 3(e)), resulting from industrial effluent discharge and agricultural runoff. The EC value of the entire basin is less than $1,000 \mu \mathrm{S} / \mathrm{cm}$, which is the threshold value for water to be described as unpolluted and fresh.

$\mathrm{COD}$ and $\mathrm{BOD}_{5}$ determine the level of organic pollution in lakes and rivers. COD estimates biodegradable and non-biodegradable contamination, while $\mathrm{BOD}_{5}$ defines the biodegradable fractions. The COD and $\mathrm{BOD}_{5}$ values in the water collected from the Garra River ranged from $8 \mathrm{mg} / \mathrm{L}$ to $51 \mathrm{mg} / \mathrm{L}$ and $6 \mathrm{mg} / \mathrm{L}$ to $27 \mathrm{mg} / \mathrm{L}$, respectively. However, in the tributaries, these values ranged from $19 \mathrm{mg} / \mathrm{L}$ to $36 \mathrm{mg} / \mathrm{L}$ and $11 \mathrm{mg} / \mathrm{L}$ to $20 \mathrm{mg} / \mathrm{L}$, respectively (Fig. 2(a)). It can be seen from Fig. 2(a) that the COD and $\mathrm{BOD}_{5}$ values in the middle and downstream of the river increase significantly, which may be due to the high effluent discharge from storm drainage, industries and flushing of sewage directly into the river by urban settlements. The sampling sites GR12 and GR17 show a high increase in values of COD and BOD5, which may be due to the presence of pulp industries, sugar industries and thermal power plants in the vicinity of these sampling sites. The overall values meets the environment protection rules established by the Central Pollution Control Board [47], which describes COD and $\mathrm{BOD}_{5}$ limits of inland surface waters of $250 \mathrm{mg} / \mathrm{L}$ and $30 \mathrm{mg} / \mathrm{L}$ respectively. However, these values exceeds drinking threshold values, which should be less than $10 \mathrm{mg} / \mathrm{L}$ and $5 \mathrm{mg} / \mathrm{L}$ in the case of COD and $\mathrm{BOD}_{5}$, respectively.

The intensity of non-compound, free oxygen present in the river water is called dissolved oxygen (DO). It is an important parameter for investigating water quality because of its impact on organisms living in water. Too low or too high level of DO can affect water quality and endanger aquatic life. The DO values did not show large spatial variations in the Garra River and its tributaries, ranging from $7.38 \mathrm{mg} / \mathrm{L}$ to $8.92 \mathrm{mg} / \mathrm{L}$ and $7.3 \mathrm{mg} / \mathrm{L}$ to $8.67 \mathrm{mg} / \mathrm{L}$, respectively (Fig. 2(b)). This indicates that water quality is not harmful to the aquatic environment.

\subsubsection{Concentration of major ions and its possible sources}

$\mathrm{Li}^{+}$elements are found in nature mostly in the clay fraction of the soil, potable water, surface water, groundwater and marine waters as well [48]. In surface waters, the assessment of $\mathrm{Li}^{+}$concentration is often overlooked because it naturally exists at low concentration (usually $<0.04 \mathrm{mg} / \mathrm{L} ;[49,50]$ ). The concentration of $\mathrm{Li}^{+}$ ranged from $0.111 \mathrm{mg} / \mathrm{L}$ to $0.54 \mathrm{mg} / \mathrm{L}$, with an average of 0.19 $\mathrm{mg} / \mathrm{L}$ in the Garra River. However, in the case of tributaries, the range was between $0.114 \mathrm{mg} / \mathrm{L}$ to $0.32 \mathrm{mg} / \mathrm{L}$, with an average of $0.16 \mathrm{mg} / \mathrm{L}$. The higher variation in the values of $\mathrm{Li}^{+}$concentration from upstream to downstream (Fig. S3(a)) suggests that the difference in sampling location has a major control over the $\mathrm{Li}^{+}$content. Weathering of rocks such as sandstone and limestone [51] may be responsible for the concentration of $\mathrm{Li}^{+}$in the upper reaches of the Garra River. In the middle and downstream of the river, anthropogenic sources may be the main cause of $\mathrm{Li}^{+}$concentration, including waste disposal and industrial wastewater, as the use of $\mathrm{Li}^{+}$includes pharmaceuticals, synthetic rubber, chemical manufacturing, lubricants and batteries [52].

Through the weathering processes, $\mathrm{Na}^{+}$and $\mathrm{K}^{+}$are washed away from the soil and rocks in the catchment area. Rivers generally contain about $9 \mathrm{mg} / \mathrm{L}$ and $2-3 \mathrm{mg} / \mathrm{L}$ of $\mathrm{Na}^{+}$and $\mathrm{K}^{+}$, respectively; however, these concentrations may fluctuate due to geological conditions and wastewater contamination (https://www.lenntech.com/ periodic/water/). The concentration of $\mathrm{Na}+$ and $\mathrm{K}^{+}$in the Garra River ranged from $3.3 \mathrm{mg} / \mathrm{L}$ to $47.4 \mathrm{mg} / \mathrm{L}$ and $0.5 \mathrm{mg} / \mathrm{L}$ to 11.0 $\mathrm{mg} / \mathrm{L}$ with an average of $21.2 \mathrm{mg} / \mathrm{L}$ and $5.8 \mathrm{mg} / \mathrm{L}$, respectively. As seen from the Fig. S3(b), the concentration of $\mathrm{Na}^{+}$and $\mathrm{K}^{+}$in the upper reaches of the river is not very high and may be dissolved through weathering processes. The middle and lower reaches of the river show a large increase in $\mathrm{Na}^{+}$and $\mathrm{K}^{+}$values, which is the result of human activities, because these regions are densely populated and have more industrial and agricultural activities. Wastewater discharged from industries and agricultural runoff is a possible cause of elevated concentrations of $\mathrm{Na}^{+}$and $\mathrm{K}^{+}$. Since, $\mathrm{Na}^{+}$is used in various industrial purposes, such as the chemical industries, it is converted to sodium hydroxide, chlorine gas or sodium carbonate, food industries as a flavouring agent or a preservative, leather and textile industries and in cleanser and soap production. $\mathrm{K}^{+}$is commonly used in synthetic fertilizers, glass production, fluid soap production, medicines, photography tanning, etc.

Multivalent cations and anions are the cause of water hardness, and in most cases, this is due to $\mathrm{Mg}^{2+}$ and $\mathrm{Ca}^{2+}$. In this study, 

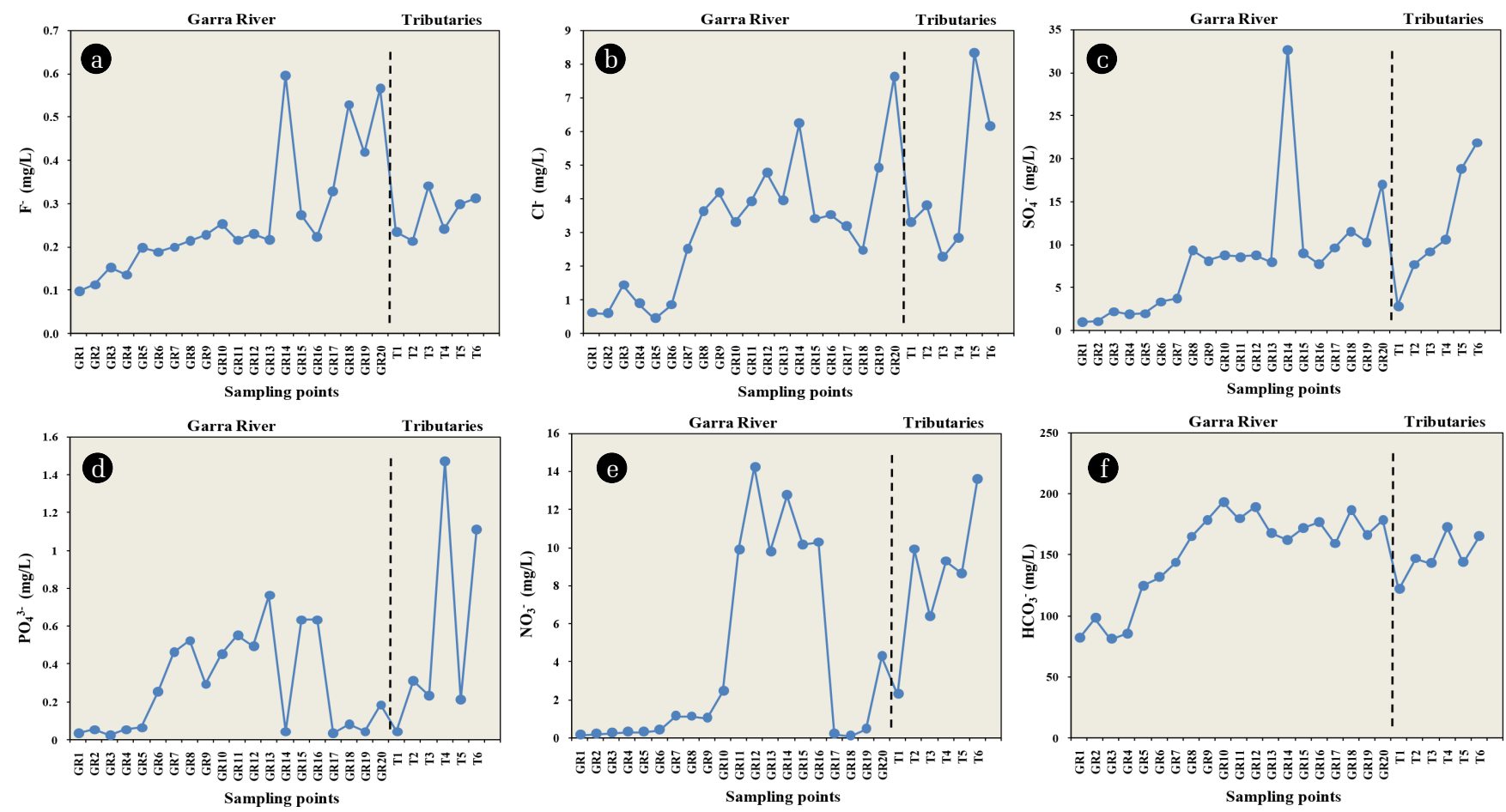

Fig. 3. (a) - (f) Spatial variations in $\mathrm{F}^{-}, \mathrm{Cl}^{-}, \mathrm{SO}_{4}{ }^{2-}, \mathrm{PO}_{4}{ }^{3-}, \mathrm{NO}_{3}{ }^{-}$and $\mathrm{HCO}_{3}{ }^{-}$in water of Garra River and its tributaries.

the $\mathrm{Mg}^{2+}$ and $\mathrm{Ca}^{2+}$ hardness are expressed as Eq. (1) [46] in terms of the equivalent of calcium carbonate.

$$
\text { Hardness }\left(\text { as } \mathrm{CaCO}_{3}\right)=\mathrm{M}^{2+} \mathrm{x} \frac{50}{\text { Eq. Wt. of } \mathrm{M}^{2+}}
$$

Among them, $\mathrm{M}^{2+}$ stands for divalent metallic ion. The total hardness is described as an increase in the hardness of $\mathrm{Mg}^{2+}$ and $\mathrm{Ca}^{2+}$, which is 65 to $70 \mathrm{mg} / \mathrm{L}$ as $\mathrm{CaCO}_{3}$ in the upstream (GR1, GR2, GR3, GR4) and 75 to $144 \mathrm{mg} / \mathrm{L}$ as $\mathrm{CaCO}_{3}$ in the middle and downstream (GR5 to GR20 and T1 to T6) (Fig. 3(f)). *Potasznik and Szymczyk [53] and Chapra et. al. [54] observed that the concentration of $\mathrm{Mg}^{2+}$ has been increased in the surface water due to the presence of sedimentary rocks, mainly dolomite. Weathering of rocks such as sandstone may be responsible for the concentration of $\mathrm{Mg}^{2+}$ in the upper reaches of the Garra River. WHO [44] classifies hardness ranges $>300,150-300,75-150$ and 0-75 into very hard, hard, moderately hard and soft, respectively. Therefore, the water of the mainstream and its tributaries is in soft to moderately hard category.

The amounts of $\mathrm{F}$ composition in the upper earth crust is soluble in water; therefore, it is usually present in groundwater and surface waters [55]. Fig. 3(a) shows that the $\mathrm{F}$ concentrations has a spatial variation ranging from $0.10 \mathrm{mg} / \mathrm{L}$ to $0.60 \mathrm{mg} / \mathrm{L}$ with an average concentration of $0.27 \mathrm{mg} / \mathrm{L}$. The upstream $\mathrm{F}^{-}$concentration is lower than downstream of the river, which may be the result of natural sources, such as geological, chemical, physical and the porosity and acidity of the soil and rock. The effect of anthropogenic sources on $\mathrm{F}^{-}$concentration can be seen in the middle and downstream of the river (Fig. 3(a)), mainly from GR14 to GR20. This may be due to the presence of coal-burning from the thermal power plant, brick-making industries, and the use of phosphatic fertilizer in agricultural fields [56].

The contents of $\mathrm{Cl}^{-}$and $\mathrm{SO}_{4}{ }^{2-}$ in the Garra River ranged from $0.43 \mathrm{mg} / \mathrm{L}$ to $8.33 \mathrm{mg} / \mathrm{L}$ and from $0.97 \mathrm{mg} / \mathrm{L}$ to $32.71 \mathrm{mg} / \mathrm{L}$, with an average concentration of $3.42 \mathrm{mg} / \mathrm{L}$ and $9.06 \mathrm{mg} / \mathrm{L}$, respectively. From Fig. 3b and 3c, it is evident that the concentrations of $\mathrm{Cl}^{-}$ and $\mathrm{SO}_{4}^{2-}$ in the upstream are lower compared to the downstream of the river and can be attributed to the same reason as F. Typically, the $\mathrm{SO}_{4}{ }^{2-}$ and $\mathrm{Cl}^{-}$ions in the river water are introduced by effluent from the anaerobic wastewater treatment plant and chloride used in the tertiary treatment, respectively. The absence of these wastewater treatment plants may also be a possible cause of $\mathrm{Cl}^{-}$and $\mathrm{SO}_{4}{ }^{2-}$ concentration throughout entire sampling period. However, the average values of $\mathrm{Cl}^{-}$and $\mathrm{SO}_{4}{ }^{2-}$ in river water are within the limits specified by BIS [43] and WHO [44].

$\mathrm{PO}_{4}{ }^{3-}$ in rivers is usually the result of runoff from agricultural fields sprayed with fertilizers and effluent discharge from sewage treatment plants [3, 57]. Another anthropogenic source is water containing dissolved detergents which are discharged into the river and increase $\mathrm{PO}_{4}{ }^{3-}$ concentration of the river due to $\mathrm{PO}_{4}{ }^{3-}$ additive (an essential ingredient in detergent). The concentration of $\mathrm{PO}_{4}{ }^{3-}$ in the river ranged from $0.02 \mathrm{mg} / \mathrm{L}$ to $1.47 \mathrm{mg} / \mathrm{L}$, with an average of $0.35 \mathrm{mg} / \mathrm{L}$ (Fig. 3(d)). Generally, the $\mathrm{PO}_{4}{ }^{3-}$ concentration is found to be higher in the downstream region of the river. These high values of $\mathrm{PO}_{4}{ }^{3-}$ may be the result of agricultural runoff, as the area is dominated by agricultural practices.

The main source of $\mathrm{NO}_{3}^{-}$in river is decaying legumes, but the oxidation of animal and human excreta also contribute a lot. In addition, municipal emissions are also a very high contributor, 
especially for facilities that do not have a nitrogen removal method. In the Garra River, the $\mathrm{NO}_{3}{ }^{-}$concentration ranged from $0.09 \mathrm{mg} / \mathrm{L}$ to $14.24 \mathrm{mg} / \mathrm{L}$, with an average concentration of $4.99 \mathrm{mg} / \mathrm{L}$ (Fig. 3(e)). The $\mathrm{NO}_{3}{ }^{-}$concentration in all samples collected during the campaign was recorded below the BIS [43] and WHO [44] limit of $45 \mathrm{mg} / \mathrm{L}$ and $50 \mathrm{mg} / \mathrm{L}$, respectively, for methaemoglobinaemia in children. Therefore, from this perspective, it makes water safe.

The concentration of $\mathrm{HCO}_{3}^{-}$in the Garra River ranged from $80.8 \mathrm{mg} / \mathrm{L}$ to $193.5 \mathrm{mg} / \mathrm{L}$, with an average concentration of 150.64 mg/L (Fig. 3(f)). In the upper reaches of the river, the concentration of $\mathrm{HCO}_{3}{ }^{-}$is mainly attributed to the weathering of silicates and carbonates rock. However, in the middle and downstream regions, these concentrations increase and the effects of anthropogenic activity may be a possible factor.

\subsection{Stretch Wise Classification of the River Water}

To understand the overall quality of water in the Garra River catchment, the entire basin is divided into four sections, and the water quality parameters of each section are averaged. The initial stretch of the Garra River basin contains rivers flowing through the lower part of the Kumaon Himalayas. The water quality along this stretch was found to be better than the other stretches. The average concentrations of $\mathrm{COD}$ and $\mathrm{BOD}_{5}$ in this section of the river were 15.6 $\mathrm{mg} / \mathrm{L}$ and $7.4 \mathrm{mg} / \mathrm{L}$, respectively. Compared with other sections, ions like $\mathrm{F}^{-}, \mathrm{SO}_{4}{ }^{2-}$ and $\mathrm{NO}_{3}{ }^{-}$in the water collected from this stretch were also found to be the lowest (Table 1). These results can be attributed to relatively few anthropogenic, agricultural and industrial activities in this stretch.

In terms of organic content, the third and fourth sections of the Garra River from Bisalpur to Shahjahanpur and Shahjahanpur to Kannauj were found to be the most polluted. For the mainstream, the average concentrations of $\mathrm{COD}$ and $\mathrm{BOD}_{5}$ in these areas are $>40 \mathrm{mg} / \mathrm{L}$ and $>21 \mathrm{mg} / \mathrm{L}$, respectively. Similarly, for tributaries, these values are $>22 \mathrm{mg} / \mathrm{L}$ and $>15 \mathrm{mg} / \mathrm{L}$, respectively. The high values in these sections are mainly due to the human influence, because the catchment areas between these regions are densely populated, and there are several industries, such as sugar, paper, thermal power plant, and direct discharge from sewage treatment plants into river.

\subsection{Statistical Analysis of the Data}

\subsubsection{Pair sample t-test}

Paired sample t-test, sometimes referred to as dependent sample t-test. This is a statistical procedure used to determine if the average difference between the two sets of perceptions is zero. The results obtained for the $t$-test are shown in Table S2. Except for $\mathrm{Ca}^{2+}$ and $\mathrm{HCO}_{3}^{-}$, all other parameters (COD, $\mathrm{BOD}_{5}, \mathrm{~F}^{-}, \mathrm{Cl}^{-}, \mathrm{SO}_{4}{ }^{2-}, \mathrm{PO}_{4}{ }^{3-}$, $\mathrm{NO}_{3}{ }^{-}, \mathrm{Li}^{+}, \mathrm{Na}^{+}, \mathrm{K}^{+}$, and $\mathrm{Mg}^{2+}$ ) were subjected to the $t$-test do not show any critical variation in their means. In the $t$-test, the p-value was found to be higher than the significant value $(\mathrm{p}<0.05)$ in case of all parameters except $\mathrm{HCO}_{3}{ }^{-}$.

Therefore, we can conclude that there is no direct contributor of organic (COD, $\left.\mathrm{BOD}_{5}\right)$, nutrient $\left(\mathrm{PO}_{4}{ }^{3-}, \mathrm{NO}_{3}{ }^{-}\right.$), minerals $\left(\mathrm{F}^{-}, \mathrm{Cl}^{-}\right.$, $\mathrm{SO}_{4}{ }^{2-}, \mathrm{Li}^{+}, \mathrm{Na}^{+}, \mathrm{K}^{+}, \mathrm{Ca}^{2+}$ and $\mathrm{Mg}^{2+}$ ) content to the mainstream except tributaries water. However, $\mathrm{HCO}_{3}{ }^{-}$in the river was more than tributaries ( $\mathrm{t}$-static $=-3.802$ and $\mathrm{p}<0.05$ ). The difference may

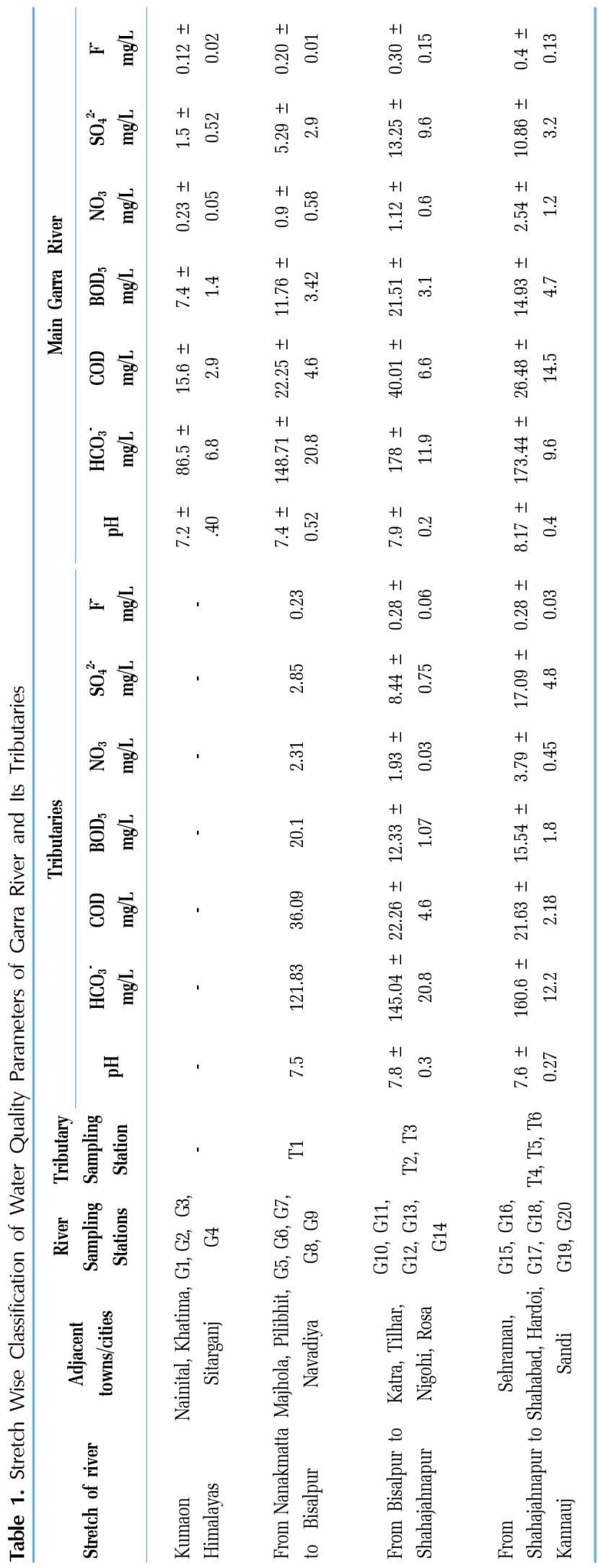


be due to the removal of free and combined carbon dioxide in the river by algae, which produced more carbonate [46].

\subsubsection{Hierarchical cluster analysis}

In order to finalize the statistical combination of the Garra River sampling sites, HCA was used. The result of this analysis led to a dendrogram (Fig. 4) having a significance at (Dlink/Dmax) x 100 $<70$. All 20 sampling locations are ultimately divided into three clusters as there were sampling sites with similar water quality and sources of pollution in these groups, and sufficient water quality information (physical, chemical, nutrient, and organic) was available.

The sampling stations (GR1 to GR8) belong to cluster 1, and pollution level is low. Due to the quiet anthropogenic, agricultural and industrial activities in the region, natural processes such as weathering and rock erosion are the main sources of pollution. Cluster 2 consists of sampling stations (GR9, GR16, GR18, GR19 and GR20) which show high levels of $\mathrm{pH}, \mathrm{EC}$, TDS, $\mathrm{NO}_{3}{ }^{-}, \mathrm{PO}_{4}{ }^{3-}$, $\mathrm{SO}_{4}^{2-}, \mathrm{F}, \mathrm{Cl}^{-}, \mathrm{Li}^{+}, \mathrm{Na}^{+}, \mathrm{K}^{+}, \mathrm{Ca}^{2+}, \mathrm{Mg}^{2+}$ and $\mathrm{HCO}_{3}^{-}$. However, turbidity, $\mathrm{COD}$ and $\mathrm{BOD}_{5}$ showed low concentration in this cluster. The sampling points belong to this cluster flow in low-lying areas, with point and non-point sources, such as various industrial emissions near Hardoi and Kannauj, agricultural activities, urban sewage and discharge from wastewater treatment plants. Cluster 3 consisting of sampling stations (GR10, GR11, GR12, GR13, GR15 and GR17) showed a lower pollution level than cluster 2 for all parameters, but the turbidity, $\mathrm{COD}$, and $\mathrm{BOD}_{5}$ concentrations were high in this cluster. The reason for the high concentration of these parameters in this cluster may be due to the discharge of industrial effluents from industries such as paper and pulp, fertilizer, sugar and distillery. The sampling station GR14 does not belong to any cluster and it shows a very high concentration of all parameters. This may be due to the discharge wastewater from the thermal power plant [58] at Rosa town; therefore, it should be sampled separately in future sampling. These results indicate that for grouping of sampling stations, cluster analysis is a useful method

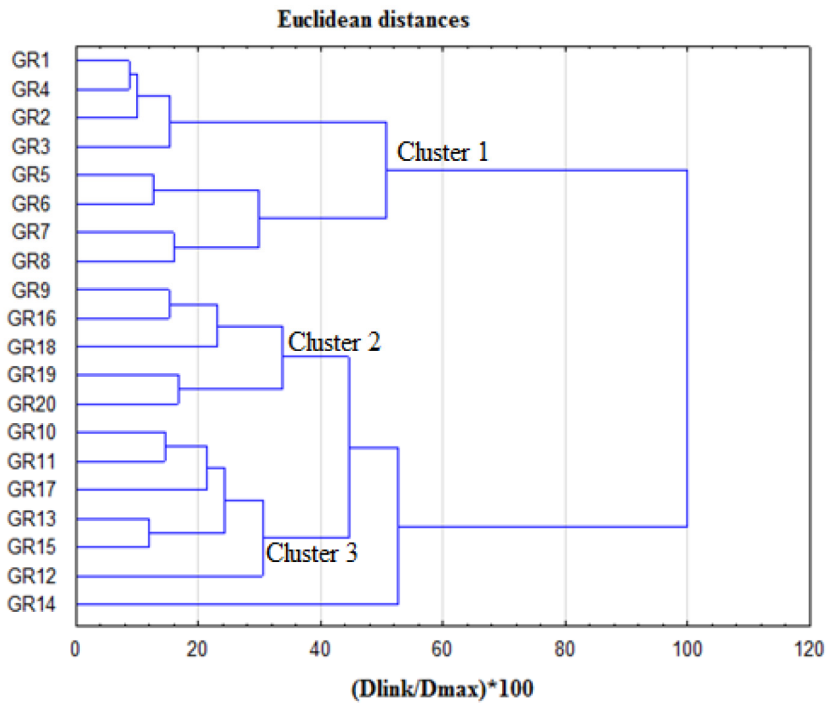

Fig. 4. Dendogram showing sampling site clusters on the Garra River. consistent with its interrelated features, thus saving time, cost-effectiveness, and most favourable river sampling in the future. Kim and Mueller [59] and Kazi et al. [60] also used the same procedure in their study to assess potential observed water quality plans.

\subsubsection{Source Identification of Pollution by Principal Component Analysis (PCA) and Correlation Matrix}

The spatial correlation matrix of the water quality parameters is obtained by PCA, as shown in Table S3. Most of the parameters in Table S3 show a positive correlation with other parameters, except for a few such as $\mathrm{Li}^{-}$and DO. Every value shows the changeability of a parameter for another parameter in the matrix, and the underlined values show a high and positive correlation. $\mathrm{pH}$ and EC are significantly positively correlated with $\mathrm{Mg}^{+}$and TDS, respectively. TDS is significantly positively correlated with $\mathrm{Ca}$, $\mathrm{HCO}_{3}{ }^{-}$and $\mathrm{Cl}^{-}$. COD and BOD are positively correlated with each other. $\mathrm{DO}$ and $\mathrm{Li}^{-}$do not show any significant correlation with any parameters. $\mathrm{NO}_{3}{ }^{-}$shows a good and positive correlation with $\mathrm{PO}_{4}^{2-}$ and $\mathrm{Mg}^{+}$.

$\mathrm{PO}_{4}^{2-}$ also showed a good and positive correlation with parameters such as $\mathrm{Ca}, \mathrm{Mg}^{+}$, and $\mathrm{HCO}_{3}^{-}$. $\mathrm{Na}^{+}$is positively correlated with $\mathrm{K}^{+}$. Ca is significantly positively correlated with $\mathrm{Mg}^{+}$and $\mathrm{HCO}_{3}^{-}$; however, $\mathrm{Mg}^{+}$shows a good and positive correlation with $\mathrm{HCO}_{3}^{-}$, $\mathrm{F}$, and $\mathrm{Cl}^{-}$. $\mathrm{SO}_{4}{ }^{2-}$ also showed a good and positive correlation with $\mathrm{F}^{-}$and $\mathrm{Cl}^{-}$. The combined insightful connections between physicochemical parameters indicates that water quality is primarily controlled by carbonate weathering. There are likewise chances of the existence of dolomite, a common source of $\mathrm{Mg}^{+}$and $\mathrm{Ca}^{+}$. A significant correlation between $\mathrm{Fl}^{-}$and $\mathrm{Ca}^{+}$also indicates the presence of minerals like fluorapatite, apatite, and fluorspar. At point scales, geochemistry can be controlled by anthropogenic sources, such as mass bathing and the use of excess fertilizers, and can be revealed by a significant correlations between $\mathrm{Cl}^{-}, \mathrm{SO}_{4}{ }^{2-}$ and $\mathrm{NO}_{3}^{-}$[61]. In this way, it can be seen that anthropogenic, geogenic and natural processes primarily control the hydro-geochemistry of the Garra River.

The scree plot (Fig. S4) was utilized to distinguish the number of principal components (PCs) to understand the basic structure of the data [62]. After the $5^{\text {th }}$ eigenvalue, the slope indicated by scree plot changes significantly. Cattell and Jaspers [63] recommend using each PC and the $1^{\text {st }}$ PC after the break, with the goal of retaining four PCs, whose eigenvalues are more noteworthy than solidarity, and clarify $81.5 \%$ of the fluctuations or data contained in the original data set.

Loadings refers to the projection of the original variable on the subspace of the PC and correspond to the correlation coefficient between the variable and the PC. There were three PCs with eigenvalues $>1$, accounting for about $77.61 \%$ of the total data set variation. Table 2 shows the loading of six maintained PCs.

PC1 explained a variance of 53.6\%, and most parameters such as $\mathrm{F}^{-}, \mathrm{Cl}^{-}, \mathrm{pH}, \mathrm{HCO}_{3}{ }^{-}, \mathrm{NO}_{3}{ }^{-}, \mathrm{SO}_{4}{ }^{2-}, \mathrm{PO}_{4}{ }^{2-}, \mathrm{EC}, \mathrm{TDS}, \mathrm{Ca}^{+}, \mathrm{Mg}^{+}$, and BOD were significantly involved (Table 2). The starting point of these variables may be shared and may form the weathering of marl, gypsum and limestone soils. Considering the large amount of oxygen consumed by the increase in dissolved organic matter, 
Table 2. Loadings of 17 Experimental Variables on Six Significant Principal Components for 20 River Water Samples

\begin{tabular}{|c|c|c|c|c|c|c|}
\hline Variable & PC1 & PC2 & PC3 & PC4 & PC5 & PC6 \\
\hline $\mathrm{Mg}^{+}$ & $\underline{0.912}$ & -0.216 & -0.187 & 0.097 & -0.120 & -0.104 \\
\hline $\mathrm{Cl}^{-}$ & $\underline{0.868}$ & -0.065 & 0.034 & 0.119 & 0.171 & -0.067 \\
\hline TDS & $\underline{\mathbf{0 . 8 6 6}}$ & -0.021 & 0.430 & -0.129 & 0.157 & 0.084 \\
\hline $\mathrm{HCO}_{3}^{-}$ & $\underline{\mathbf{0 . 8 6 6}}$ & 0.041 & 0.154 & 0.259 & -0.258 & -0.124 \\
\hline $\mathrm{Ca}^{+}$ & $\underline{0.861}$ & 0.166 & 0.136 & 0.335 & -0.131 & 0.085 \\
\hline $\mathrm{EC}$ & $\underline{0.808}$ & -0.030 & 0.263 & -0.254 & 0.161 & 0.402 \\
\hline $\mathrm{PO}_{4}{ }^{2-}$ & $\underline{0.789}$ & -0.209 & -0.028 & 0.344 & -0.288 & 0.283 \\
\hline $\mathrm{SO}_{4}{ }^{2-}$ & $\underline{0.766}$ & 0.088 & -0.283 & 0.123 & $\underline{0.507}$ & -0.177 \\
\hline BOD & $\underline{0.737}$ & 0.374 & -0.242 & -0.369 & -0.081 & 0.153 \\
\hline $\mathrm{F}^{-}$ & $\underline{0.730}$ & -0.322 & -0.246 & 0.077 & $\underline{0.468}$ & -0.004 \\
\hline $\mathrm{pH}$ & $\underline{0.726}$ & -0.299 & 0.028 & -0.309 & -0.022 & -0.437 \\
\hline $\mathrm{NO}_{3}^{-}$ & $\underline{0.721}$ & $\underline{-0.583}$ & 0.067 & -0.076 & -0.102 & 0.098 \\
\hline COD & $\underline{0.647}$ & $\underline{0.468}$ & -0.214 & $\underline{-0.497}$ & -0.183 & 0.062 \\
\hline $\mathrm{K}^{+}$ & $\underline{0.629}$ & $\underline{0.538}$ & 0.197 & 0.017 & -0.246 & -0.384 \\
\hline $\mathrm{Na}^{+}$ & $0 . \underline{540}$ & $\underline{0.742}$ & 0.209 & 0.129 & 0.124 & 0.054 \\
\hline $\mathrm{Li}^{-}$ & 0.035 & $\underline{0.686}$ & $\underline{-0.662}$ & 0.195 & 0.009 & 0.099 \\
\hline DO & $\underline{-0.438}$ & $\underline{0.583}$ & $\underline{0.551}$ & 0.056 & 0.267 & -0.017 \\
\hline Eigenvalue & 9.110 & 2.675 & 1.408 & 0.966 & 0.935 & 0.706 \\
\hline \% Variance explained & 53.590 & 15.736 & 8.285 & 5.682 & 5.501 & 4.152 \\
\hline$\%$ Cum. variance & 53.590 & 69.327 & 77.611 & 83.293 & 88.794 & 92.946 \\
\hline
\end{tabular}

\#Bold values denote loadings of interest

the positive loading of $\mathrm{COD}$ and $\mathrm{BOD}_{5}$ in $\mathrm{PC} 1$ can be elucidated because organic matter is mainly composed of carbohydrates in urban wastewater, and organic acids. DO have negative participation, and $\mathrm{Li}^{-}$shows positive but not important participation in PC1. PC2 explained a variance of $15.8 \%$, including $\mathrm{Na}^{+}, \mathrm{Li}^{-}$ and DO (positive loading), and $\mathrm{NO}_{3}^{-}$(negative participation). PC3, PC4 and PC5 explained $8.3 \%, 5.7 \%$ and $5.5 \%$ of the total variance, respectively.

\subsubsection{Spatial variations in quality of river water by analysis of} variance (one-way ANOVA)

The importance of spatial variation in physicochemical parameters between the Garra River and its tributaries and between each sampling location is determined by one-way ANOVA statistical method. When the $p$ value was less than 0.05 ( $p<0.05$ ), a significant change was considered. Table 3 shows the water sample variations analyzed by ANOVA between the Garra River and its tributaries. Except for turbidity, $\mathrm{K}^{+}$, and $\mathrm{HCO}_{3}{ }^{-}$, all other parameters did not show any significant change. The variation in turbidity, $\mathrm{K}^{+}$and $\mathrm{HCO}_{3}{ }^{-}$may be due to leaching of the rocks along the path of the Garra river, while the tributaries have local flow. However, in the case of spatial variation between each sampling point, a highly significant variation is exhibited by turbidity, $\mathrm{NO}_{3}^{-}, \mathrm{Na}^{+}, \mathrm{K}^{+}, \mathrm{Mg}^{+}$ and $\mathrm{HCO}_{3}^{-}$. Sampling points on the Garra river were intercepted in various tributaries, which may have changed the nature of pollution and the value of pollution parameters.
Table 3. The Result of ANOVA Analysis between the Garra River and Its Tributaries and between Each Sampling Location

\begin{tabular}{|c|c|c|}
\hline Variables & $\begin{array}{l}\text { Between Garra River } \\
\text { and its tributary }\end{array}$ & Between each point \\
\hline $\mathrm{pH}$ & $\mathrm{NS}(\mathrm{P}=0.207)$ & $\mathrm{NS}(\mathrm{P}=0.283)$ \\
\hline Turbidity (NTU) & ${ }^{* *}(\mathbf{P}=\mathbf{0 . 0 0 0})$ & ${ }^{* *}(\mathbf{P}=\mathbf{0 . 0 0 1})$ \\
\hline $\mathrm{EC}(\mu \mathrm{S} / \mathrm{cm})$ & $\mathrm{NS}(\mathrm{P}=0.066)$ & $\mathrm{NS}(\mathrm{P}=0.087)$ \\
\hline TDS (mg/L) & $\mathrm{NS}(\mathrm{P}=0.198)$ & $\mathrm{NS}(\mathrm{P}=0.066)$ \\
\hline COD (mg/L) & $\mathrm{NS}(\mathrm{P}=0.077)$ & $\mathrm{NS}(\mathrm{P}=0.178)$ \\
\hline BOD (mg/L) & $\mathrm{NS}(\mathrm{P}=0.151)$ & $\mathrm{NS}(\mathrm{P}=0.058)$ \\
\hline DO (mg/L) & $\mathrm{NS}(\mathrm{P}=0.436)$ & $\mathrm{NS}(\mathrm{P}=0.129)$ \\
\hline $\mathrm{NO}_{3}^{-}(\mathrm{mg} / \mathrm{L})$ & $\mathrm{NS}(\mathrm{P}=0.066)$ & ${ }^{* *}(\mathbf{P}=\mathbf{0 . 0 0 3})$ \\
\hline $\mathrm{PO}_{4}{ }^{3-}(\mathrm{mg} / \mathrm{L})$ & $\mathrm{NS}(\mathrm{P}=0.690)$ & $\mathrm{NS}(\mathrm{P}=0.081)$ \\
\hline $\mathrm{Li}$ (mg/L) & $\mathrm{NS}(\mathrm{P}=0.058)$ & $\mathrm{NS}(\mathrm{P}=0.296)$ \\
\hline $\mathrm{Na}(\mathrm{mg} / \mathrm{L})$ & $\mathrm{NS}(\mathrm{P}=0.094)$ & ${ }^{*}(P=0.031)$ \\
\hline $\mathrm{K}(\mathrm{mg} / \mathrm{L})$ & ${ }^{*}(P=0.039)$ & ${ }^{* *}(\mathbf{P}=\mathbf{0 . 0 0 4})$ \\
\hline Ca (mg/L) & $\mathrm{NS}(\mathrm{P}=0.143)$ & $\mathrm{NS}(\mathrm{P}=0.836)$ \\
\hline $\mathrm{Mg}(\mathrm{mg} / \mathrm{L})$ & $\mathrm{NS}(\mathrm{P}=0.134)$ & ${ }^{* *}(\mathbf{P}=\mathbf{0 . 0 0 2})$ \\
\hline $\mathrm{HCO}_{3}(\mathrm{mg} / \mathrm{L})$ & ${ }^{*}(\mathrm{P}=0.041)$ & ${ }^{* *}(\mathbf{P}=\mathbf{0 . 0 0 4})$ \\
\hline
\end{tabular}

\#NS $=$ non significant; ${ }^{* *}=$ highly significant; ${ }^{*}=$ significant 


\subsection{Concentration of Heavy Metals}

Heavy metal pollution in the river water is one of the most important concerns of rural and urban communities in developing nations. The entry of these toxic heavy metals into the environment may lead to bioaccumulation and biomagnifications [64]. Heavy metals pollution in the riverine environments has received global attention due to its persistence, abundance and environmental toxicity [65, 66]. To observe the concentration of heavy metals in the Garra River, Fe, Zn, and Mn in the collected water samples were analysed in AAS. The analysis showed that all samples contained Fe, Zn and $\mathrm{Mn}$, including mainstream and tributaries.

Fig. 5 (a) and (b) show the concentration of Fe, Zn and Mn in the Garra River and its tributaries. As can be seen from the figure, the concentration of $\mathrm{Fe}$ in the mainstream and the tributaries is very high, while the concentrations of $\mathrm{Zn}$ and $\mathrm{Mn}$ are also high, but lower compared with Fe. The concentration of Fe ranges from $0.205 \mathrm{mg} / \mathrm{L}$ to $55.99 \mathrm{mg} / \mathrm{L}$, with an average concentration of 17.31 $\mathrm{mg} / \mathrm{L}$ in the Garra River. In the case of tributaries, the concentration of Fe is $0.73 \mathrm{mg} / \mathrm{L}$ to $51.92 \mathrm{mg} / \mathrm{L}$, with an average concentration of $16.94 \mathrm{mg} / \mathrm{L}$. In case of the Garra River, the concentrations of $\mathrm{Zn}$ and $\mathrm{Mn}$ ranges from $0.002 \mathrm{mg} / \mathrm{L}$ to $0.84 \mathrm{mg} / \mathrm{L}$ and $0.01 \mathrm{mg} / \mathrm{L}$ to $0.83 \mathrm{mg} / \mathrm{L}$, with an average concentration of $0.14 \mathrm{mg} / \mathrm{L}$ and 0.25 $\mathrm{mg} / \mathrm{L}$, respectively. However, in the case of tributaries, they are in the range of $0.02 \mathrm{mg} / \mathrm{L}$ to $0.18 \mathrm{mg} / \mathrm{L}$ and $0.005 \mathrm{mg} / \mathrm{L}$ to $0.69 \mathrm{mg} / \mathrm{L}$, with an average concentration of $0.10 \mathrm{mg} / \mathrm{L}$ and $0.24 \mathrm{mg} / \mathrm{L}$, respectively.
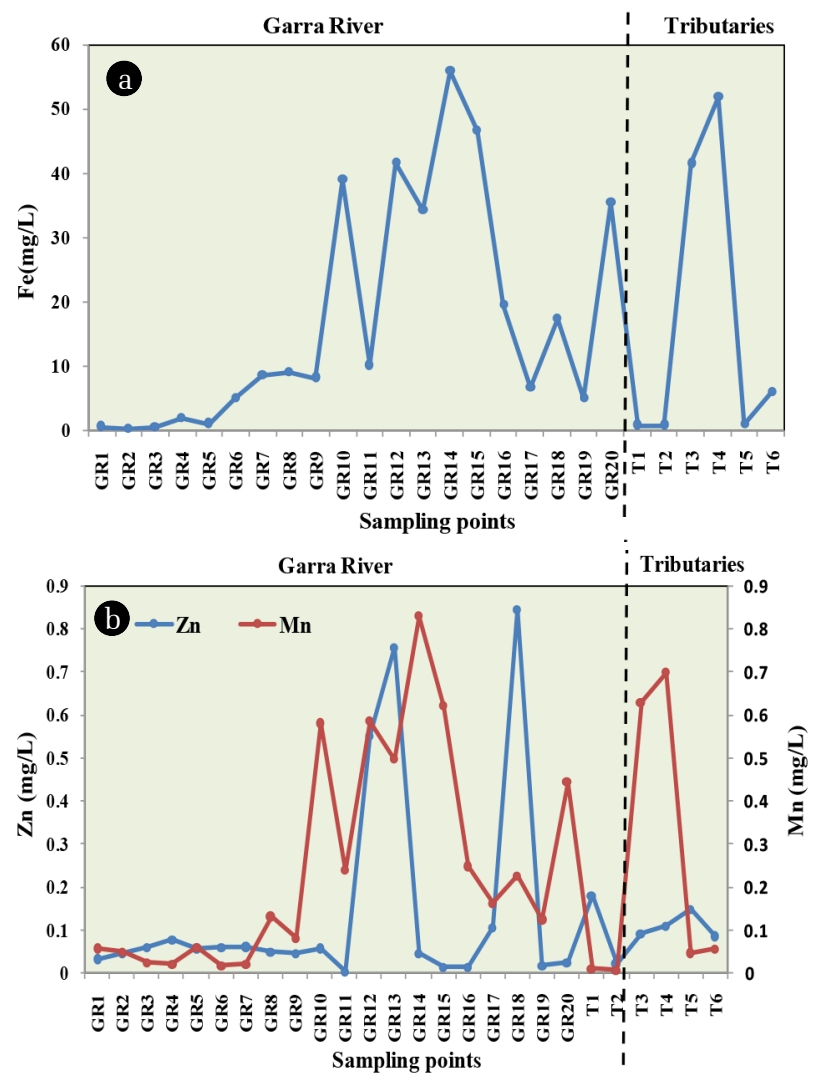

Fig. 5. Spatial variations in heavy metals (a) Fe and (b) Zn and Mn in water of main stream and its tributaries.
As can be seen from Fig. 5(a) and (b), the concentrations of $\mathrm{Fe}, \mathrm{Zn}$ and $\mathrm{Mn}$ show an increased pattern from upstream to downstream. The upstream Fe concentration is mainly from natural iron sources, which may be due to the presence of silicate rock weathering [67] in the upper part of the basin. The middle stream and downstream of the Garra River and its tributaries are contaminated with medium to high heavy metals at several locations, which may be the results of the dense population (Fig. S1(d)) and high industrial and agricultural activity in these stretches of the Garra basin. The primary anthropogenic sources are the discharge of partially treated and untreated industrial wastewater and sewage containing toxic metals. In addition, it comes from the widespread use of metal chelates in a wide range of industries and pesticides and fertilizers containing heavy metals in the agricultural sector [68, 69]. The average value of $\mathrm{Zn}$ in case of the Garra River and its tributaries is much lower than the approved limit of BIS [43]. However, the $\mathrm{Fe}$ and $\mathrm{Mn}$ concentrations in mainstream and tributaries show high values from the drinking limits recommended by BIS [43] and WHO [44].

\section{Conclusions}

The study was designed to assess the water quality parameters of the Garra River and its tributaries. The sampling points located downstream of the river show that the concentration of $\mathrm{PO}_{4}{ }^{3-}$ is as high as $0.4-0.5 \mathrm{mg} / \mathrm{L}$. The downstream section of the river in GFP from Bisalpur to Shahjahanpur and from Shahjahanpur to Kannauj contains more $\mathrm{SO}_{4}{ }^{2-}$ and organic content compared to the upstream section in GFP and Kumaon hills. A paired sample t-test indicating that $\mathrm{HCO}_{3}^{-}$in the river was more than tributaries. Approximately $77 \%$ of the total variation can be explained by extracted PC, which has an eigenvalue $>1$ and shows the positive and heavy loadings of the river's mineral portion. One-way ANOVA clarified turbidity, $\mathrm{K}^{+}$and $\mathrm{HCO}_{3}{ }^{-}$are parameters having considerable variation between the Garra River and its tributaries. However, $\mathrm{NO}_{3}^{-}, \mathrm{Na}^{+}, \mathrm{K}^{+}, \mathrm{Mg}^{+}$and $\mathrm{HCO}_{3}^{-}$are parameters that show significant variation between each location of the Garra River.

Turbidity, $\mathrm{Li}+, \mathrm{HCO}_{3}^{-}, \mathrm{Fe}$, and $\mathrm{Mn}$ are the most important parameters affecting the water quality of the Garra river. The potential sources of in the Garra River is the dissolution of rocks through chemical and physical weathering processes in the upstream of the river. In the middle and lower reaches of the river, pollution is mainly due to the human influence as the catchment area in between is densely populated. The other sources of pollution in the middle and lower reaches of the river is the presence of various industries, such as sugar industries, paper industries, thermal power plant and sewage discharged directly from sewage treatment plants into rivers. The downstream region of the river containing sample locations from GR9 to GR20 shows high levels of contamination in terms of physicochemical parameters and heavy metals.

These methods can help water quality monitoring agencies to improve current monitoring program(s) by reducing the number of monitoring stations to the ones that best represent the spatial pattern of river water quality. Ultimately, this will help reduce the time, effort, and cost of assessing river water quality. 
Some of the limitations in the conclusions drawn from this study may be that large data sets that multivariate techniques need to provide meaningful results are not available. However, as the first study on the Garra River Basin, our research can be used as a case study to further strengthen the research findings of river water quality. In addition, results based on descriptive statistics are also presented in our investigation, which will help to assess comparatively future datasets with this study.

\section{Acknowledgments}

We would like to thank to deanship of scientific research (DSR) at King Abdulaziz University (KAU)-Jeddah, Saudi Arabia for providing funding support (D1441-559-145) in completion of this article.

\section{Author Contributions}

M.Y.A.K. (Assistant Professor) conducted all the experiments and wrote the manuscript. M.Y.A.K. (Assistant Professor) and J.W. (Research Associate) revised and edited the manuscript.

\section{References}

1. Manahan SE. Environmental chemistry of water. In: fundamentals of environmental chemistry. 1st ed. Boca Raton, Florida, United States: CRC Press; 1993. p. 373-413.

2. Bricker OP, Jones BF. Main factors affecting the composition of natural waters. In: Salbu B Steinnes E, eds. Trace elements in Natural Waters. Boca Raton, Florida, United States: CRC Press; 1995. p. 1-20.

3. Carpenter SR, Caraco NF, Correll DL, Howarth RW, Sharpley AN, Smith VH. Nonpoint pollution of surface waters with phosphorus and nitrogen. Ecol. Appl. 1998;8(3):559-568.

4. Jarvie HP, Whitton BA, Neal C. Nitrogen and phosphorus in east coast British rivers: speciation, sources and biological significance. Sci. Total Environ. 1998;210:79-109.

5. Khan MY, Khan B, Chakrapani GJ. Assessment of spatial variations in water quality of Garra River at Shahjahanpur, Ganga Basin, India. Arab. J. Geosci. 2016a;9(8):516.

6. Khan MY, Gani KM, Chakrapani GJ. Assessment of surface water quality and its spatial variation. A case study of Ramganga River, Ganga Basin, India. Arab. J. Geosci. 2016b;9(1):28.

7. Kumar A, Sharma MP, Taxak AK. Analysis of water environment changing trend in Bhagirathi tributary of Ganges in India. Desal. Water Treat. 2017;63:55-62.

8. Khan MY, Gani KM, Chakrapani GJ. Spatial and temporal variations of physicochemical and heavy metal pollution in Ramganga River - a tributary of River Ganges, India. Environ. Earth Sci. 2017;76(5):231.

9. Khan MY, Tian F. Understanding the potential sources and environmental impacts of dissolved and suspended organic carbon in the diversified Ramganga River, Ganges Basin, India. Proc. Int. Assoc. Hydrol. Sci. 2018;379:61-66.
10. Li Y, Khan MY, Jiang Y, et al. CART and PSO+ KNN algorithms to estimate the impact of water level change on water quality in Poyang Lake, China. Arab. J. Geosci. 2019;12(9):287.

11. Finnveden G, Hauschild MZ, Ekvall T, et al. Recent developments in life cycle assessment. J. Environ. Manage. 2009;91(1):1-21.

12. Dixon W, Chiswell B. Review of aquatic monitoring program design. Water Res. 1996;30(9):1935-1948.

13. Kumar A, Sharma MP, Yadav NS. Assessment of Water Quality Changes at Two Locations of Chambal River: MP. J. Mater. Environ. Sci. 2014;5(6):1781-1785.

14. Mishra S, Sharma MP, Kumar A. Assessment of Water Quality in Surha Lake Based on Physiochemical Parameters, India. J. Mater. Environ. Sci. 2015;6:2446-2452.

15. Singh KP, Malik A, Mohan D, Sinha S. Multivariate statistical techniques for the evaluation of spatial and temporal variations in water quality of Gomti River (India) - a case study. Water Res. 2004;38(18):3980-3992.

16. Ouyang Y, Nkedi-Kizza P, Wu QT, Shinde D, Huang CH. Assessment of seasonal variations in surface water quality. Water Res. 2006;40(20):3800-3910.

17. Shrestha S, Kazama F. Assessment of surface water quality using multivariate statistical techniques: A case study of the Fuji river basin, Japan. Environ. Modell. Softw. 2007;22(4): 464-475.

18. Razmkhah H, Abrishamchi A, Torkian A. Evaluation of spatial and temporal variation in water quality by pattern recognition techniques: a case study on Jajrood River (Tehran, Iran). J. Environ. Manage. 2010;91(4):852-860.

19. Zhao J, Fu G, Lei K, Li Y. Multivariate analysis of surface water quality in the Three Gorges area of China and implications for water management. J. Environ. Sci. 2011;23(9):1460-1471.

20. Bu H, Meng W, Zhang Y. Spatial and seasonal characteristics of river water chemistry in the Taizi River in Northeast China. Environ. Monit. Assess. 2014;186(6):3619-3632.

21. Tanos P, Kovács J, Kovács S, Anda A, Hatvani IG. Optimization of the monitoring network on the River Tisza (Central Europe, Hungary) using combined cluster and discriminant analysis, taking seasonality into account. Environ. Monit. Assess. 2015;187(9):575.

22. Bonansea M, Ledesma C, Rodriguez C, Pinotti L. Water quality assessment using multivariate statistical techniques in Río Tercero Reservoir, Argentina. Hydrol. Res. 2015;6(3):377-388.

23. Phung D, Huang C, Rutherford S, et al. Temporal and spatial assessment of river surface water quality using multivariate statistical techniques: a study in Can Tho City, a Mekong Delta area, Vietnam. Environ. Monit. Assess. 2015;187(5):229.

24. Varekar V, Karmakar S, Jha R. Seasonal rationalization of river water quality sampling locations: a comparative study of the modified Sanders and multivariate statistical approaches. Environ. Sci. Pollut. R. 2016;23(3):2308-2328.

25. Gangapedia. About us: Gangapedia. Retrieved Dec 20, 2013, Available from http://gangapedia.iitk.ac.in/?q=content/about-us

26. Kazmi AA, Hansen IS. Numerical models in water quality management: a case study for the Yamuna river (India). Water Sci. Technol. 1997;36(5):193.

27. Singh KP, Malik A, Sinha S. Water quality assessment and 
apportionment of pollution sources of Gomti river (India) using multivariate statistical techniques - a case study. Anal Chim Acta. 2005;538(1-2):355-374.

28. Mishra S, Kumar A, Shukla P. Study of water quality in Hindon River using pollution index and environmetrics, India. Desalination Water Treat. 2016;57(41):19121-19130.

29. Mishra S, Kumar A, Shukla P. Study of water quality in Hindon River using pollution index and environmetrics, India. Desalin. Water Treat. 2016;57(41):19121-19130.

30. Parmar KS, Bhardwaj R. Statistical, time series, and fractal analysis of full stretch of river Yamuna (India) for water quality management. Environ. Sci. Pollut. R. 2015;22(1):397-414.

31. Sharma D, Kansal A, Pelletier G. Water quality modeling for urban reach of Yamuna river, India (1999-2009), using QUAL2Kw. Appl. Water Sci. 2017;7(3):1535-1559.

32. Khan MY, Chakrapani GJ. Particle size characteristics of Ramganga catchment area of Ganga River. InGeostatistical and geospatial approaches for the characterization of natural resources in the environment 2016; pp. 307-312. Springer, Cham

33. Khan MY, Daityari S, Chakrapani GJ. Factors responsible for temporal and spatial variations in water and sediment discharge in Ramganga River, Ganga Basin, India. Environ. Earth Sci. 2016c;75(4):283.

34. Khan MY, Hasan F, Panwar S, Chakrapani GJ. Neural network model for discharge and water-level prediction for Ramganga River catchment of Ganga Basin, India. Hydrolog Sci. J. 2016d;61(11):2084-2095.

35. Khan MY. Spatial variation in the grain size characteristics of sediments in Ramganga River, Ganga Basin, India. Handbook of environmental materials management. Springer, Berlin. 2018

36. Daityari S, Khan MY. Temporal and spatial variations in the engineering properties of the sediments in Ramganga River, Ganga Basin, India. Arab. J. Geosci. 2017;10(6):134.

37. Khan MY, Tian F, Hasan F, Chakrapani GJ. Artificial neural network simulation for prediction of suspended sediment concentration in the River Ramganga, Ganges Basin, India. Int. J. Sediment Res. 2019a;34(2):95-107.

38. Khan MY, Hasan F, Tian F. Estimation of suspended sediment load using three neural network algorithms in Ramganga River catchment of Ganga Basin, India. Sustain. Water Resour. Manag. 2019b;5(3):1115-1131.

39. Khan MY, Hu H, Tian F, Wen J. Monitoring the spatio-temporal impact of small tributaries on the hydrochemical characteristics of Ramganga River, Ganges Basin, India. Int. J. River Basin Manag. 2019c:1-1.

40. Gupta RP, Joshi BC. Landslide hazard zoning using the GIS approach - a case study from the Ramganga catchment, Himalayas. Eng. Geol. 1990;28(1-2):119-131.

41. Khan AU, Rawat BP. Quaternary geology and geomorphology of a part of Ganga basin in parts of Bareilly, Badaun, Shahjahanpur and Pilibhit district, Uttar Pradesh. 1992 Geological Survey of India (GSI).

42. American Public Health Association (APHA). AWWA and WPCF Standard Methods for the Examination of Waters and Waste Waters. 20th ed. Washington DC; 1998.

43. Bureau of Indian Standards (BIS: 10500). Indian standard specification for drinking water. Second Revision. New Delhi; 1989.
44. World Health Organization (WHO). Guidelines for drinking water quality: recommendations, 3rd edn. Geneva; 2008.

45. Rao CS, Rao BS, Hariharan AV, Bharathi NM. Determination of water quality index of some areas in Guntur district Andhra Pradesh. Int. J. Appl. Biol. Pharm. Technol. 2010;1(1):79-86.

46. Sawyer CN, McCarty PL, Parkin GF. Chemistry for environmental engineering and science. New York: McGraw-Hill; 2003.

47. Central Pollution Control Board (CPCB). The Environment (Protection) Rules. Schedule - VI., Ministry of Water Resources, Government of India, New Delhi; 1986.

48. Kostik V, Bauer B, Kavrakovski Z. Lithium content in potable water, surface water, ground water, and mineral water on the territory of Republic of Macedonia. Int. J. Med. Public Health. 2014;4(3).

49. Hill BR, Gilliom RJ. Streamflow, dissolved solids, suspended sediment, and trace elements, San Joaquin River, California, June 1985-September 1988. US Department of the Interior, US Geological Survey; 1993.

50. Tanner DQ. Surface-water-quality Assessment of the Lower Kansas River Basin, Kansas and Nebraska: Distribution of Trace-element Concentrations in Dissolved and Suspended Phases, Streambed Sediment, and Fish Samples, May 1987 Through April 1990. US Department of the Interior, US Geological Survey; 1995.

51. Vine JD, Dooley JR Jr. Where on earth is all the lithium? With a section on uranium isotope studies, Fish Lake Valley, Nevada, United States Geological Survey open-file report 80-1234, Denver: Colorado; 1980.

52. Kszos LA, Stewart AJ. Review of lithium in the aquatic environment: distribution in the United States, toxicity and case example of groundwater contamination. Ecotel. 2003;12(5):439-47.

53. Potasznik A, Szymczyk S. Magnesium and calcium concentrations in the surface water and bottom deposits of a river-lake system. J. Elem. 2015;20(3).

54. Chapra SC, Dove A, Warren GJ. Long-term trends of Great Lakes major ion chemistry. J. Great Lakes Res. 2012;38(3):550-560.

55. Frencken, J.E. (editor). Endemic Fluorosis in developing countries, causes, effects and possible solutions. Publication number 91.082, NIPG-TNO, Leiden, The Netherlands; 1992.

56. Jha SK, Mishra VK, Sharma DK, Damodaran T. Fluoride in the environment and its metabolism in humans. In: Reviews of Environmental Contamination and Toxicology. Springer New York; 2011. p. 121-142.

57. Wiens JH. Agricultural Runoff and Water Pollution. Can Water Resour J. 1980;5(3):78-89.

58. Baba A, Kaya A, Birsoy YK. The effect of Yatagan thermal power plant (Mugla, Turkey) on the quality of surface and ground waters. Water Air Soil Poll. 2003;149(1-4):93-111.

59. Kim JO, Mueller CW. Introduction to factor analysis: what it is and how to do it. Quantitative applications in the social sciences series. Newbury Park: Sage University Press; 1978.

60. Kazi TG, Arain MB, Jamali MK, et al. Assessment of water quality of polluted lake using multivariate statistical techniques: A case study. Ecotox. Environ. Safe. 2009;72(2):301-9.

61. Avtar R, Kumar P, Singh CK, et al. Hydrogeochemical assessment of groundwater quality of Bundelkhand, India using statistical approach. Water Qual. Expos. Hea. 2013;5(3):105-15. 
62. Jackson JE. A User's Guide to Principal Components. Wiley, New York; 1991.

63. Cattell RB, Jaspers J. A general plasmode (No. 30-10-5-2) for factor analytic exercises and research. Mult. Behav. Res. Monog. 1967;67:1:212-266.

64. Paul D. Research on heavy metal pollution of river Ganga: A review. Ann. Agric. Sci. 2017;15(2):278-286.

65. Ahmed MK, Baki MA, Islam MS, et al. Human health risk assessment of heavy metals in tropical fish and shellfish collected from the river Buriganga, Bangladesh. Environ. Sci. Pollut. Res. 2015;22(20):15880-15890.

66. Islam MS, Ahmed MK, Habibullah-Al-Mamun M, Hoque MF.
Preliminary assessment of heavy metal contamination in surface sediments from a river in Bangladesh. Environ. Earth Sci. 2015;73(4):1837-1848.

67. Krachler R, Jirsa F, Ayromlou S. Factors influencing the dissolved iron input by river water to the open ocean. Biogeosciences 2005;2(4):311-315.

68. Abbasi SA, Abbasi N, Soni R. Heavy Metals in the Environment. New Delhi: Mittal Publications; 1998.

69. Reza R, Singh G. Heavy metal contamination and its indexing approach for river water. Int. J. Environ. Sci. Techol. 2010;7(4):785-792. 